\title{
Southern House Spider, Kukulcania (= Filistata) hibernalis Hentz (Arachnida: Arneae: Filistatidae) ${ }^{1}$
}

\author{
G. B. Edwards and K. McCanless ${ }^{2}$
}

\section{Introduction}

The southern house spider, Kukulcania (Filistata) hibernalis Hentz, is a conspicuous arachnid in Florida due to its relatively large size and distinctive flat, tangled web. It is common throughout Florida and much of the southern United States in human populated areas. Males of this species are often mistaken for the notorious brown recluse spider, Loxosceles reclusa Gertsch and Mulaik, because of their color and general shape. Southern house spiders are not known to have a dangerous bite. However, two bite cases reportedly caused the victims pain and swelling for a few days.

\section{Systematics}

The southern brown spider was previously listed in the genus Filistata, but is now listed in the genus Kukulcania. Spiders in the family Filistatidae are most frequently associated systematically with other families which have structures called a cribellum (a silk-producing plate found anterior to the spinnerets) and a calamistrum (a row of specialized setae on the 4th metatarsus used for pulling silk from the cribellum).

\section{Description}

Kukulcania hibernalis is a species that exhibits a great degree of sexual dimorphism. Females are charcoal gray and 13-19 mm in length. Females often have dusky patches on the carapace. The abdomen is elongate-ovoid, and at times can be considerably distended, e.g., after feeding or if the female is gravid. The male spider is $9-10 \mathrm{~mm}$ in length, khaki to amber in color and has long slender legs and palpi (the distal segments of the latter fold back along the proximal segments). Males also have a brown stripe from behind the eye prominence, which narrows quickly to include only the thoracic groove. The violin mark of the brown recluse is conspicuously wider and continues to the posterior edge of the carapace. Also, male K. hibernalis are generally larger than L. reclusa, have much longer legs and palpi, and have eight eyes grouped together on a raised prominence, rather than the six eyes in three pairs possessed by L. reclusa.

1. This document is EENY-144, one of a series of Featured Creatures from the Entomology and Nematology Department, Florida Cooperative Extension Service, Institute of Food and Agricultural Sciences, University of Florida. Published: July 2000. Revised: June 2003. This document is also available on Featured Creatures Website at http://creatures.ifas.ufl.edu. Please visit the EDIS Website at http://edis.ifas.ufl.edu. Additional information on these organisms, including many color photographs, is available at the Entomology and Nematology Department website at http://entnemdept.ifas.ufl.edu/.

2. G. B. Edwards, Florida Department of Agriculture, Division of Plant Industry, Gainesville, FL and K. McCanless, Entomology and Nematology Department, University of Florida, Insititute of Food and Agricultural Sciences, Gainesville, FL 32611.

The Institute of Food and Agricultural Sciences is an equal opportunity/affirmative action employer authorized to provide research, educational information and other services only to individuals and institutions that function without regard to race, color, sex, age, handicap, or national origin. For information on obtaining other extension publications, contact your county Cooperative Extension Service office. Florida Cooperative Extension Service/Institute of Food and Agricultural Sciences/University of Florida/Christine Taylor Waddill, Dean. 


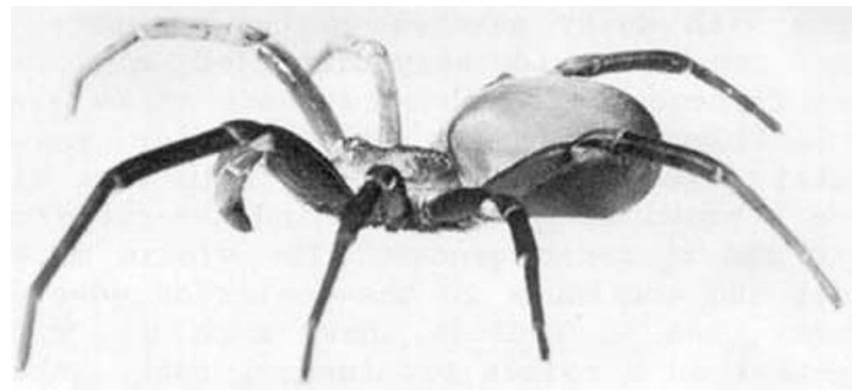

Figure 1. Lateral view of female southern house spider, Kukulcania (Filistata) hibernalis Hentz. Credits: Division of Plant Industry

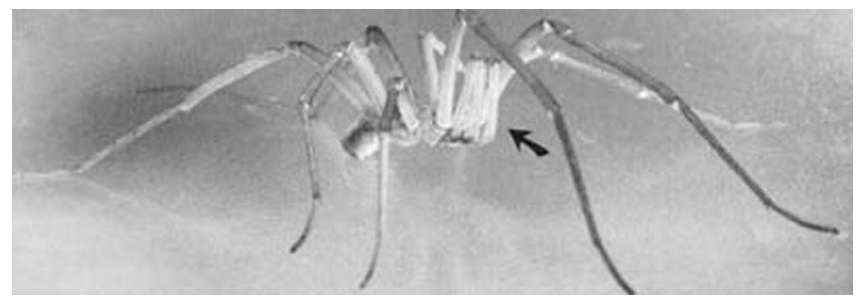

Figure 2. Lateral view of male southern house spider, Kukulcania (Filistata) hibernalis Hentz, showing elongated palpi (arrow). Credits: Division of Plant Industry

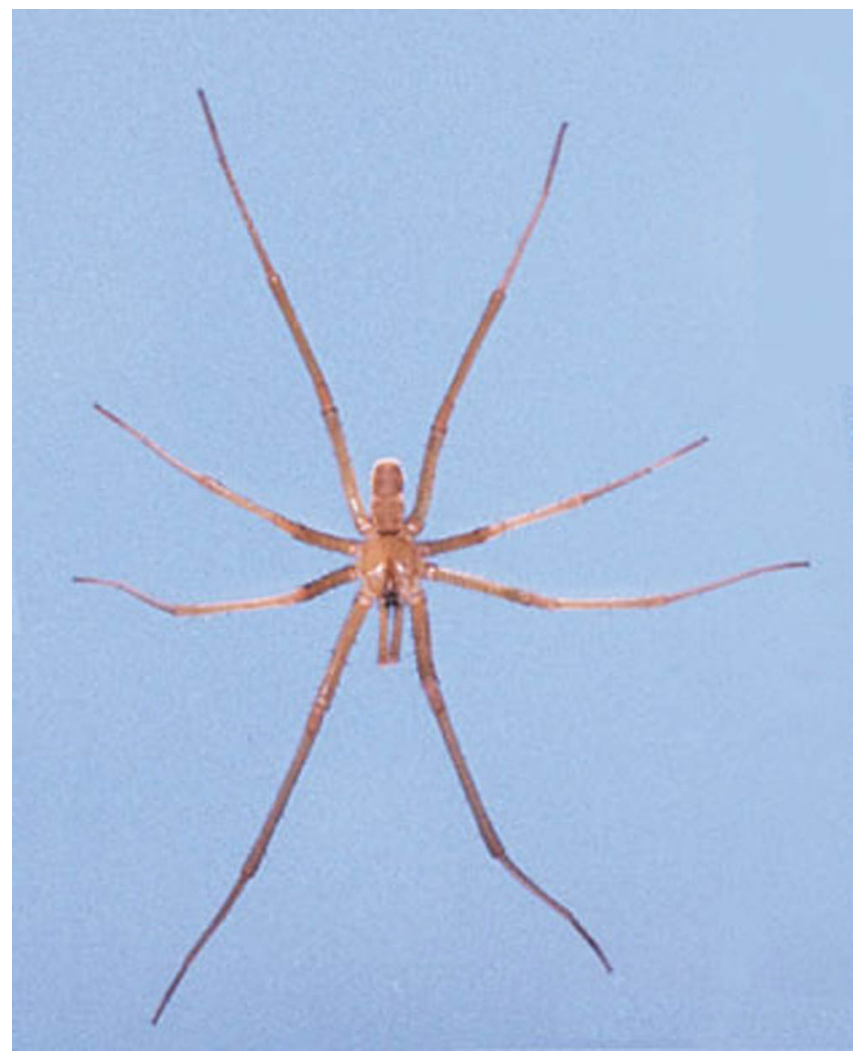

Figure 3. Dorsal view of male southern house spider, Kukulcania (Filistata) hibernalis Hentz. Credits: Jeffrey Lotz, Division of Plant Industry

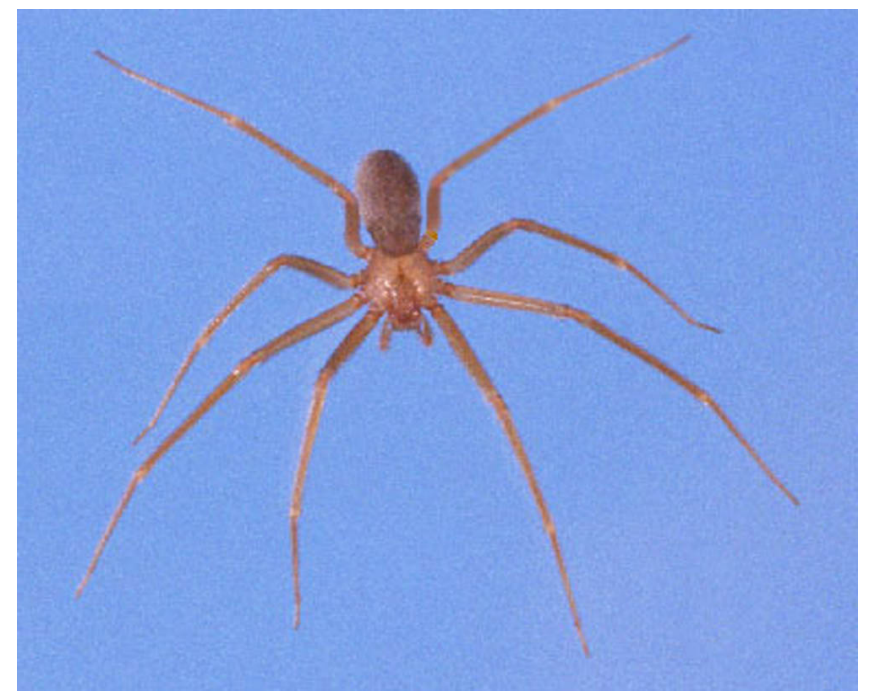

Figure 4. Female brown recluse spider, Loxosceles reclusa Gertsch and Mulaik, dorsal view for comparison with dorsal view of male southern house spider, Kukulcania (Filistata) hibernalis Hentz. Credits: Jeffrey Lotz, Division of Plant Industry

\section{Habits and Habitats}

The southern house spider is partial to spaces within the masonry of buildings; especially dark recesses of windowsills, shutters and overhangs. Females and juveniles make specialized webs that are occasionally found under tree bark but are frequently seen on houses, barns, bridges, and other man-made structures. Here a spider seeks out a sheltered crevice for a nest, around which a distinctive web is made on the adjoining substrate. Under microscopic inspection, the silk of this web appears to be "wooly", an appearance created by the action of the calamistrum pulling silk from the cribellum. This web lacks sticky droplets which are characteristic of entrapment strands in webs of some other spider families. Rather, with $K$. hibernalis, the structure of the web itself is responsible for entangling prey. Males do not build webs but instead wander in search of females in order to mate. Females lay about 200 eggs that are loosely swathed in a silken ball about 15 $\mathrm{mm}$ in diameter and are kept with the female in her nest. In Florida, all stages of development seem to be present throughout the year. Females may live up to eight years (Kaston 1972).

These spiders are generally found within their distinctive tangled web in holds or spaces within the masonry of buildings especially along dark recesses of windowsills, shutters, and overhangs. These webs 


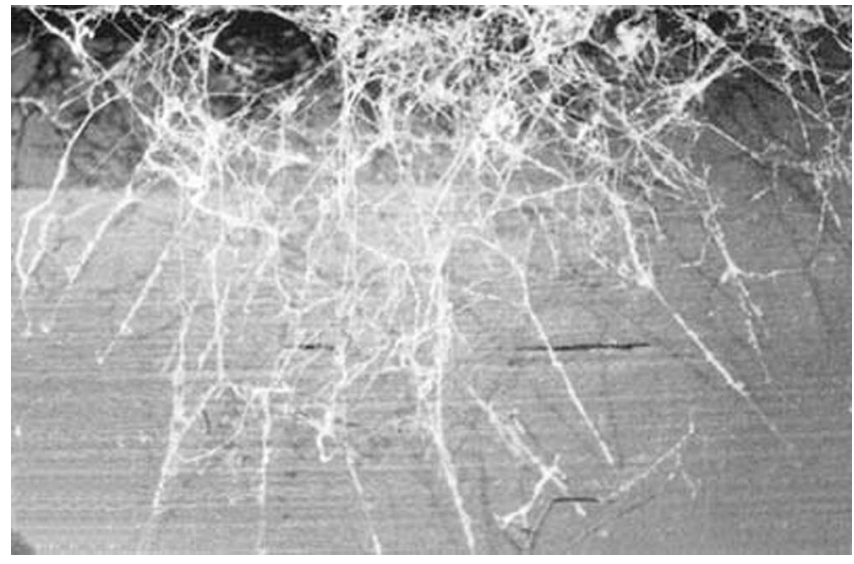

Figure 5. Web of the southern house spider, Kukulcania (Filistata) hibernalis Hentz. Credits: Division of Plant Industry

have a decidedly unkempt appearance with debris and body parts of insect prey they have devoured.

Although the webs tend to accumulate debris and may be unsightly to some, this harmless spider is beneficial and captures many pest insects, including house flies, horse flies mud daubers, cockroaches, and May beetles.

\section{Survey and Detection}

The distinctive tangled, unkempt web easily identifies the presence of this spider. The eye protuberance, size and color of both sexes, and the ling legs and palpi of the males aid in field identification. Wandering males are easily captured in shell vials; females must usually be trapped outside the nest on the web.

\section{Management}

Spiders are often in or around building because they prey on insects that are attracted to the lights. To prevent indoor spider infestations, cracks and crevices in window casings should be repaired, and spaces above and below doors should be sealed. Holes at entry points of water pipes and electrical lines should be plugged and screens should be kept securely on chimneys. The use of window and door screens (or repairing damage screens) can also help reduce insect and subsequent spider invasions into the residence.

Routine vacuuming can eliminate spiders over time by removing the food source. Periodic vacuuming along baseboards, under furniture, or other undisturbed areas near the floor of the home, will remove webs, nests, and egg sacs. Firewood should be inspected for spiders or egg sacs before being brought into the house. In rare instances where spiders are numerous and constantly entering the house, you may wish to use an insecticide. These materials are best applied only where spiders are present.

\section{Insect Management Guide for Spiders}

\section{Selected References}

Hentz NM. 1842. Descriptions and figures of the Araneides of the United States. Boston Journal of Natural History 4:223-231.

Kaston BJ. 1972. How to know the spiders, 3rd edition. Wm. C. Brown, Co., Dubuque, Iowa. 272p.

Lehtinen PT. 1967. Classification of the cribellate spiders and some allied families, with noted on the evolution of the suborder Araneomorpha. Ann. Zool. Fenn. 4:199-468.

Levi HW. 1982. Araneae. Pp. 77-95 in S.P. Parker, ed. Synopsis and Classification of living organisms, Vol. 2. McGraw-Hill Book Co., New York.

Schreiber ET, Edwards GB. Florida Spiders: biology and control. EntGuide. http://pherec.org/entguides/EntGuide7-Spiders.html (11 June 2000) 